\title{
Institutions and corporate governance
}

Citation for published version (APA):

Chen, L. (2013). Institutions and corporate governance. [Doctoral Thesis, Maastricht University]. Maastricht University. https://doi.org/10.26481/dis.20130314lc

Document status and date:

Published: 01/01/2013

DOI:

10.26481/dis.20130314lc

Document Version:

Publisher's PDF, also known as Version of record

\section{Please check the document version of this publication:}

- A submitted manuscript is the version of the article upon submission and before peer-review. There can be important differences between the submitted version and the official published version of record.

People interested in the research are advised to contact the author for the final version of the publication, or visit the DOI to the publisher's website.

- The final author version and the galley proof are versions of the publication after peer review.

- The final published version features the final layout of the paper including the volume, issue and page numbers.

Link to publication

\footnotetext{
General rights rights.

- You may freely distribute the URL identifying the publication in the public portal. please follow below link for the End User Agreement:

www.umlib.nl/taverne-license

Take down policy

If you believe that this document breaches copyright please contact us at:

repository@maastrichtuniversity.nl

providing details and we will investigate your claim.
}

Copyright and moral rights for the publications made accessible in the public portal are retained by the authors and/or other copyright owners and it is a condition of accessing publications that users recognise and abide by the legal requirements associated with these

- Users may download and print one copy of any publication from the public portal for the purpose of private study or research.

- You may not further distribute the material or use it for any profit-making activity or commercial gain

If the publication is distributed under the terms of Article $25 \mathrm{fa}$ of the Dutch Copyright Act, indicated by the "Taverne" license above, 


\section{Introduction}

Governance mechanisms are deeply embedded in the surrounding legal and economic context. First, corporate governance designs evolve over time as the institutional environment is reshaped. Many institutional reforms initiated by regulators have far-reaching implications for the governance of public firms. The examples in the US include the erection of a wide variety of anti-takeover defences since the late 1980s, the amended proxy rules introduced in the early 1990s, the adoption of the "Fair Disclosure" regulation in 2000, and the passage of the Sarbanes-Oxley Act of 2002, undoubtedly the most comprehensive corporate governance reform program in the US since the 1930s. Second, corporate governance designs are characterized by considerable cross-sectional variations because of different institutional contexts. Just as no single political constitution is universally adopted by all nations, no unique set of governance rules can be applied to different corporations and economies all over the world. An important stream of the literature, known as the comparative corporate governance literature, has proliferated, aiming at exploiting the rich diversity of corporate governance mechanisms across countries, and comparing their strengths and weaknesses.

Having embraced the idea that corporate governance and the institutional context tend to be intertwined, I demonstrate in this dissertation how (i) boards of directors have responded to regulatory reforms and escalated public scrutiny since the early 2000s (Chapters 2 and 3) and (ii) the incidences of financial fraud committed by cross-listed firms, the spillover effect, and the moderating role of reputable auditors are related to their home countries' corporate governance levels (Chapter 4).

My investigation into the market for independent directors yields interesting findings: despite the unambiguous increase in the demand for independent directors since 2000 because of new governance reforms, independent directors have reduced their board seats since then as a response to the increased workload and risk. The important questions that have not been addressed so far, however, are what type of firms these directors depart from, to what extent these departure decisions are period-specific, and how the gap between increased demand and decreased supply is filled. In adjusting their directorship portfolio, incumbent directors are more likely to depart firms that are costly to monitor and advise during the period when public scrutiny is high, while this finding is not observed during the low-scrutiny period. Despite shrinking supply from the incumbent director pool, a substantial number of new directors enter the market to satisfy demand. These new directors are more likely to be 
financial experts (audit committee member) and are more likely to be recruited by firms that are costly to monitor and advise, results which are again specific to the high-scrutiny period. These findings suggest that, although it is never a purpose of the governance reforms, firms that have higher monitoring/advising cost tend to lose incumbent directors and have to recruit unseasoned new directors instead.

Having examined how the market for independent directors evolves as the institutional environment is reshaped; I shift my focus on comparative corporate governance research. More specifically, using data on shareholder-initiated class action lawsuits in the US, I investigate financial misconducts of US-listed foreign firms. After controlling for type I errors (e.g. frivolous lawsuits), I document that firms domiciled in the countries with weak corporate governance were more likely to commit fraud, but such relation could be moderated by the presence of Big 4 auditors. Investors automatically adjusted for type II errors (e.g. undiscovered fraud) when valuating the stocks of non-sued firms. That is, nonsued firms that shared the same countries of origin with their sued peers experienced valuation declines around class periods end dates (the dates when the scandals were exposed rather than the dates when the litigations were filed). Investors relied on audit quality to form their expectations about the severity of type II errors, and thus posed less negative spillovers on firms with Big 4 auditors, especially when the firms were from countries with weak corporate governance. Taken together, my results suggest that a listing on US exchanges does not fully compensate weak local institutions; voluntarily bonding to more stringent audit process has an incremental effect on protecting shareholder interests, and enhances the confidence of investors in firms' financial integrity. 